\title{
Differential Distribution of NMDA Receptor Subunit mRNA in the Rat Cochlear Nucleus
}

\author{
KAZUO SATO, HIROMICHI KURIYAMA, AND RICHARD A. ALTSCHULER* \\ KresgeH earing Research Institute, University of Michigan, Ann Arbor, Michigan 48109-0506
}

\begin{abstract}
KEY WORDS glutamate; excitatory amino acid; in situ hybridization; brain stem; auditory
ABSTRACT The distribution and expression of mRNAs for different subunits of the N-methyl-Daspartate receptor (NMDAR) were examined in the cochlear nucleus (CN) of the rat using radioactive in situ hybridization methods. Heavy labeling for NMDAR1 subunit MRNA was observed in all major CN neuronal types with lower labeling for NMDAR2A, 2B, 2C, and 2D mRNA. Silver grain counting was used to compare expression of different NMDAR2 subunits between six of the major CN cell types. Small cells of the small cell cap/shell area had the highest expression of NMDAR2A-C subunit mRNAs of the cell types assessed. These small cells as well as fusiform and corn cells of the dorsal cochlear nucleus had higher NMDAR2C than other NMDAR2 subunits, providing these neuron types with a distinct expression pattern or profile. The other three cell types assessed, spherical bushy cells, granule cells, and octopus cells had relatively equivalent levels of NMDAR2A-C subunit expressions, providing a second distinct profile. NMDAR2D mRNA had low expression in all six cell types assessed. Microsc. Res. Tech. 41:217-223, $1998 . \quad 01998$ Wiley-Liss, Inc.
\end{abstract}

\section{NTRODUCTION}

Excitatory amino acids (EAA) are believed to be the major neurotransmitter(s) for rapid neuronal excitation. They act via excitatory amino acid receptors often termed glutamate receptors (GluR) since glutamate is the most prominent candidate for the natural ligand (e.g., Collingridge et al., 1988; Cotman and Iversen, 1987; Esclapez et al., 1993; Monaghan and Cotman, 1985; Monaghan et al., 1989; Monyer et al., 1992; Petralia et al., 1994a,b; Tölle et al., 1993). EAA neurotransmission is also related to neuronal plasticity and neurotoxicity and plays an essential role in brain function and dysfunction (Cik et al., 1993; Collingridge et al., 1988; Cotman and I versen, 1987; Hollmann et al., 1993; Monaghan et al., 1989; Monyer et al., 1991, 1992; Nakanishi et al., 1990; Nakanishi, 1992; Watkins et al., 1990).

There are both ionotropic glutamate receptors with an integral ion channel and metabotropic receptors that use $G$ proteins as second messengers. I onotropic glutamate receptors have been categorized as $\alpha$-ami no3-hydroxy-5 methyl-4 isoxazol epropinate (AMPA)-kainate receptors (Nakanishi et al., 1992) or N-methyl-Daspartate receptors (NMDARs) based on their sensitivities to selective agonists. These NMDARs have an integral ion channel containing a $\mathrm{Mg}^{2+}$ ion, which can block the receptor action unless removed as a result of post-synaptic changes, such as specific levels of depolarization. High-frequency stimulation is often necessary to produce sufficient post-synaptic depolarization to remove the $\mathrm{Mg}^{2+}$ ion and render the NMDAR active (Collingridge et al., 1988). Since the NMDAR is not always active, pharmacological studies may not detect it under all conditions. It is, therefore, useful to examine expression of the receptor (subunits) to detect the presence of the receptor. The ionotropic NMDAR also has other interesting properties, including poten- tial for modulation by glycine, polyamine activation, and $\mathrm{Zn}^{2+}$ inhibition.

NMDARs are involved in many central nervous system (CNS) synapses (e.g., Collingridge et al., 1988; Cotman and Iversen, 1987; Monaghan et al., 1989; Watkins et al., 1990). The current literature has identified five subunits of the ionotropic NMDAR: NMDAR1 and N MDAR2A through NMDAR2D (Kutsuwada et al ., 1992; Monyer et al., 1992; Moriyoshi et al., 1991; Nakanishi et al., 1992). The NMDAR1 subunit can exist in several different splicing isoforms (Durand et al., 1993; Kusiak and Norton, 1993; Laurie and Seeburg, 1994; Standaert et al., 1993). NMDAR1 subunits by themselves confer many of the characteristic properties of the NMDAR, including $\mathrm{Ca}^{2+}$ permeability, voltagedependent block by $\mathrm{Mg}^{2+}$, and glycine enhancement (Kutsuwada et al., 1992; Monyer et al., 1992). The NMDARI subunit, however, naturally forms a heteromeric configuration with NMDAR2 subunits (Monyer et al., 1992; Nakanishi, 1992). The addition of different NMDAR2 subunits provides functional variability in physiological and pharmacological properties of the NMDAR (Cik et al., 1993; Durand et al., 1993; Hollmann et al., 1993; Monyer et al., 1992; Raditsch et al., 1993).

Pharmacological, physiological, and anatomical studies provide evidence that excitatory amino acids acting at glutamate receptors are the major excitatory influence in the ascending auditory pathways (see reviews by Adams, 1993; Altschuler et al., 1986; Caspary, 1986; Caspary and Finlayson, 1991; Caspary et al., 1985; Eybalin, 1993; Godfrey et al., 1988; Helfert et al., 1991;

\footnotetext{
Contract grant sponsor: NIDCD, Contract grant number: DC00383.

*Correspondence to: Richard A. Altschuler, Ph.D., Kresge Hearing Research Institute, The University of Michigan, 1301 E. Ann Street, Ann Arbor, MI 48109-0506. E-mail: shuler@umich.edu

Received 10 J une 1997; Accepted in revised form 2 J anuary 1998
} 
J uiz et al., 1993; Manis et al., 1993; Morest, 1993; Wenthold, 1991; Wenthold et al., 1993). In the present study, the distribution of NMDAR subunits in the rat cochlear nucleus (CN) was examined using in situ hybridization methods. General mapping studies (Monyer et al., 1992; Moriyoshi et al., 1991; Nakanishi et al., 1992; Shigemoto et al., 1992; Tölle et al., 1993; Watanabe et al., 1993) have shown the presence of NMDAR in neurons in several auditory brain stem regions, including the $\mathrm{CN}$, but did not differentiate among cell types. Watanabe et al. (1993) assessed relative expression of NMDAR subunits in brain stem areas of the 21-day-old rat, including examination of several cell types in the cochlear nucleus. Our studies of glycine receptor subunits in the auditory brain stem, however, found that at 21 days of age the immature subunit (alpha 2) of the glycine receptor was more highly expressed than the mature (alpha 1) subunit (Sato et al., 1995a), with the mature composition not occurring until 8-10 weeks of age. There have been preliminary reports of NMDAR 1 expression in therat CN (Hunter et al., 1995; Sato et al., 1995b) and a recent report showing NMDAR 1 immunolocalization and expression in the mouse CN (Bilak et al., 1996). In the present study, we used nonradioactive and radioactive in situ hybridization methods to examine NMDAR1 and NMDAR2A-D receptor subunit mRNA expression in the CN of 250-300 g (8-10week-old) rats. Radioactive in situ hybridization methods were used to quantitate and compare NMDAR2A-D subunit mRNA expression between selected neuronal types by counting silver grains over somata.

\section{MATERIALS AND METHODS}

Male Sprague-Dawley rats (250-300 g) were used in this study. Oligonucleotide probes were made of the antisense codon of Moriyoshi et al.'s (1991) sequence (NMDAR1, 5'-GAA CAG GTC ACC CGT GGT CAC CAG ATC GCA CTT CTG TGAAGC CTC-3'), Monyer et al.'s (1991, 1992) sequences (NMDAR2A, 5'-AGA AGG CCC GTG GGA GCT TTC CCT TTG GCT AAG TTT C-3'; NMDAR2B, 5'-GGG CCT CCT GGC TCT CTG CCA TCG GCT AGG CAC CTG TTG TAA CCC-3'; NMDAR2C, 5'-TGG TCC ACC TTT CTT GCC CTT GGT GAG GTT CTG GTT GTA GCT-3'), and Tölle et al.'s (1993) sequence (NMDAR2D, 5'-CGT GGC CAG GCT TCG GTT ATA GCC CAC AGG ACT GAG GTA CTC-3'). The synthesized oligonucleotide probes were purified using high pressure liquid chromatography.

\section{In Situ Hybridization}

Animals were heavily anesthetized with chloral hydrate, decapitated and brains rapidly removed. The auditory brain stem was frozen onto a cryostat chuck; cryostat sections were cut at 15-18 $\mu \mathrm{m}$ and mounted onto glass slides. Mounted unfixed sections were then fixed in 4\% paraformaldehyde in $0.1 \mathrm{M}$ phosphate buffer (PB) for 2 hours, rinsed in phosphate buffered saline (PBS), and then treated with $20 \mu \mathrm{g} / \mathrm{ml}$ proteinase $\mathrm{K}$ at $37^{\circ} \mathrm{C}$. This was followed by a wash in $2 \mathrm{mg} / \mathrm{ml}$ glycine in $0.1 \mathrm{M}$ PBS. Sections were then incubated in $0.25 \%$ acetic anhydride in $0.1 \mathrm{M}$ triethanolamine $0.9 \%$ $\mathrm{NaCl}$ solution. After dehydration through graded ethanols and delipilization in chloroform, sections were air-dried. Probes were end-labeled with $\alpha{ }^{-35} \mathrm{~S}$ dATP New England Nuclear (NEN, Boston, MA) using a 3' end-labeling kit (NEN). The labeling of probes was carried out with ${ }^{35} \mathrm{~S}$ dATP in labeling reaction buffer with cobalt chloride and terminal transferase at $37^{\circ} \mathrm{C}$. Hybridization was carried out overnight at $37^{\circ} \mathrm{C}$ with ${ }^{35} \mathrm{~S}$-labeled oligonud eoti de of $2 \times 10^{5} \mathrm{cpm} / \mu$ l concentration in hybridization buffer containing $0.02 \mathrm{M}$ dithiothreitol, 10\% dextran sulfate, $1 \times$ Denhardt's solution, $4 \times$ standard sal ine citrate (SSC), $0.2 \%$ sodium dodecyl sulfate (SDS), $250 \mu \mathrm{g} / \mathrm{ml}$ yeast tRNA, $250 \mu \mathrm{g} / \mathrm{ml}$ sal mon testis DNA, and $50 \%$ dei onized formamide. Slides were then washed in $2 \times, 1 \times$, and $0.5 \times$ SSC at room temperature followed by washing in $0.5 \times \mathrm{SSC}$ at $37^{\circ} \mathrm{C}$. Sections were air-dried and dipped with autoradiography emulsion (Kodak NBT-2; Kodak, Rochester, NY) diluted 1:1 with water. The dipped slides were exposed for 4 weeks in a dark box at $4^{\circ} \mathrm{C}$ and developed. Slides then received a light $\mathrm{Niss}$ counter stain (Toluidine Blue) to assist in differentiation of neuronal cell types. Control sections were prepared with the labeled probe in the presence of 200-fold excess of unlabeled probe in the hybridization mixture. Control sections showed no appreciable amount of hybridization signal.

\section{QuantitativeAnalysis}

Quantitative analysis of NMDAR2 subunits was accomplished by silver grain counting over identified neurons using the M etaM orph ${ }^{\mathbb{}}$ I mage Acquisition and Analysis System (Universal Imaging, West Chester, PA). I mages were acquired with a Dage-MTI (Michigan City, IN) Precision 81 video camera from a Leitz (Wetzlar, Germany) Dialux microscope and digitized with a Matrox LC board (Matrox Electronic Systems, Quebec, Canada). Six comparable sections of each CN region were assessed from four rats for each subunit. Criteria were established for each cell type to be assessed based on the categorizations of Cant and Morest (1984) and Moore (1986). Chosen neurons had to be counterstained clearly, located in the central portion of the appropriate $\mathrm{CN}$ region, contain a nucleus, and meet size, shape, and location criteria. Neurons that were assessed in the small cell cap portion of the shell region (Hutson and Morest, 1996) were termed small cells and could correspond to either Hutson and Morest's (1996) definition of small stellate cells or mitral cells. They had a round shape, were 75-175 $\mu^{2}$ in size, and were in the shell region overlying ventral CN (VCN) dorsolaterally; they were larger than neurons identified as granule cells. Neurons identified as spherical bushy cells had a round-polygonal shape,

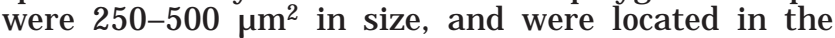
mid-to-rostral anteroventral CN (AVCN). Octopus cells

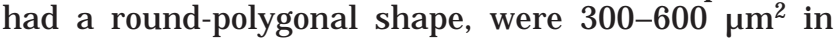
size, and were located in the octopus cell region of posteroventral CN (PVCN). Granule cells had a round shape, were 50-100 $\mu^{2}$ in size, and were located between the VCN and the dorsal CN (DCN). Fusiform cells had fusiform shapes, were $300-500 \mu \mathrm{m}^{2}$ in size, and were located in the middle layer of DCN. Corn cells (also called el ongate, tuberoventral, or fan cells) had an oval shape, were 150-300 $\mu^{2}$ in size, and were located in the deep layer of the DCN. Stellate multipolar cells were viewed as a heterogeneous group that could not be easily differentiated with the counterstain utilized and were, therefore, not counted. Cells of the molecular layer of the DCN were not counted for similar reasons. 
Ten cells per selected section, meeting cell typing criteria, were chosen from fields in the center of the appropriate $\mathrm{CN}$ region. The average silver grain density in each cell type for each subunit was therefore based on 240 representative neurons from four rats. Labeling in neuropil without cells was used to set the background levels of silver grains and subtracted from counts to equilibrate between sections. The somata of cells meeting the criteria were outlined using a mouse, and the number of silver grains over the somata was determined. This was then divided by the cell area to give density of labeling for each neuron in counts $/ \mu \mathrm{m}^{2}$. Silver grain counts were compared between cell types for each subunit using a one-way ANOVA test, with a P value bel ow 0.05 necessary for a difference to be deemed significant.

The care and use of animals reported in this study was approved and supervised by the University of Michigan Committee for the Use and Care of Animals. All subjects were treated with care under appropriate $\mathrm{NIH}$ Guidelines for the Care and Use of Laboratory Animals, and meeting AAALAC requirements.

\section{RESULTS General}

NMDAR1 subunit mRNA was detected in all major neuronal cell types of the $\mathrm{CN}$ with a very high density of silver grains over all cells (Fig. 1). NMDAR2 subunit mRNA expression was also detected in all major CN cell types, although at lower levels than NMDAR1. Levels of NMDAR2A-D labeling varied among cell types and subunits. In general, labeling was greatest in small cells of the small cell cap/shell overlying the VCN (Fig. 1a) and lowest in PVCN octopus cells (Fig. 1c) and granule cells (Fig. 1d) located between the VCN and the DCN. NMDAR2C showed the highest labeling of any NMDAR2 subunit and was greatest in the small cells of the shell region as well as in DCN fusiform cells ( $\mathrm{Fig}$. $1 \mathrm{e})$, and lower in the remaining cells types assessed. NMDAR2A showed the highest labeling in small cells of the shell region and in spherical and globular bushy cells of the VCN. NMDAR2B showed the highest labeling in small cells of the shell region. NMDAR2D had low labeling in all CN cell types.

\section{QuantitativeAnalysis}

NMDAR2A-D labeling was assessed quantitatively in six CN cell types: small cells of the small cell cap/shell area, spherical bushy cells of the AVCN, octopus cells of the PVCN, granule cells between the DCN and PVCN, and fusiform cells and corn cells of the DCN. Labeling between $3-4.9 \times 10^{-2}$ counts $/ \mu^{2}$ was considered low (+), from 5-6.9 $\times 10^{-2}$ counts $/ \mu^{2}$ was considered moderate $(++)$, from $7-8.9 \times 10^{-2}$ counts/ $\mu \mathrm{m}^{2}$ was considered high $(+++)$, and over $9 \times 10^{-2}$ counts $/ \mu \mathrm{m}^{2}$ was considered very high $(++++$ ) (see Table 2). It should be kept in mind that these are relative figures, and even very high labeling for an NMDAR2 subunit is substantially less than the NMDAR1 labeling.

NMDAR2A labeling fell into 2 groups (Tables 1, 2). The first group had moderate to high labeling with small cell cap cells showing high $(+++)$ and spherical bushy cells moderate $(++)$ label. The second group contained fusiform cells, corn cells, granule cells, and octopus cells, all with low (+) label. Expression of NMDAR2A mRNA in spherical bushy cells or small cell cap cells was significantly greater than expression in octopus cells, fusiform cells, granule cells, or corn cells. There was no significant difference in labeling within either of the two groups.

NMDAR2B also could be divided into two different groups (Tables 1,2 ). Small cell cap cells had high $(+++)$ label while all other cells assessed had low $(+)$ label. Small cell cap cells labeling was significantly higher than any of the other cell types assessed. Within the second group, there were significant differences between labeling of granule and corn cells and between octopus and granule cell labeling.

Three categories of labeling for NMDAR2C mRNA were observed (Tables 1, 2) with significant differences between the groupings. Fusiform cells and small cell cap neurons both had very high $(++++)$ label, while corn cells had only a moderate $(++)$ level, and spherical bushy cells, octopus cells, and granule cells had low levels $(+)$ (Tables 1, 2). There were no significant differences within the groupings.

The density of NMDAR2D was comparable in all six cell types. It was at a low (+) level in all CN cells assessed, highest in spherical bushy cells and lowest in octopus cells (Tables 1, 2). In all but corn cells, it had the lowest expression of the four NMDAR2 subunits.

On the basis of these patterns, it is possible to divide the six cell types assessed into three groups, as is done in Table 2. The small cells of the small cell cap/shell, fusiform cells, and corn cells of deep DCN all have relatively high NMDAR2C compared to other NMDAR2 subunits with the level lower in corn cells. Spherical bushy cells, on the other hand, have relatively higher NMDAR2A compared to other subunits. Granule cells and octopus cells both have low levels of all subunits.

\section{DISCUSSION}

The finding that NMDAR subunits are expressed in all major rat cochlear nucleus neurons is consistent with recent results in the mouse CN (Bilak et al., 1996) and not unexpected since all these cells receive excitatory amino acid input and have been shown to express AMPA receptor mRNA (Hunter et al., 1993). The finding of both NMDAR1 and R2 expression is also consistent with general CNS mapping studies (Monyer et al., 1992; Moriyoshi et al., 1991; Nakanishi et al., 1992; Watanabe et al., 1993) as well as immunocytochemical studies in the CNS and CN (Petralia et al., 1994a,b, 1996; Rubio and Wenthold, 1997; Schwartz and Eager, 1995). While there is general expression of NMDAR 1 and R2 in neurons, there are quantitative differences between neurons in the expression of NMDAR2 subunits (e.g., Moriyoshi et al., 1991; Nakanishi et al., 1992; Watanabe et al., 1993). The differences in NMDAR2 subunit expression appear to provide a molecular basis for generation of heterogeneity in physiological and pharmacological properties. Results of Buller et al. (1994) and M ishina et al. (1993) show that high expression of NMDAR2A correlates with antagonist preferring pharmacology and that high 2B expression correlates with agonist preferring pharmacology. High NMDAR2C expression confers high sensitivity to 7-chlorokynurenate (7CK) and high NMDAR2A high 


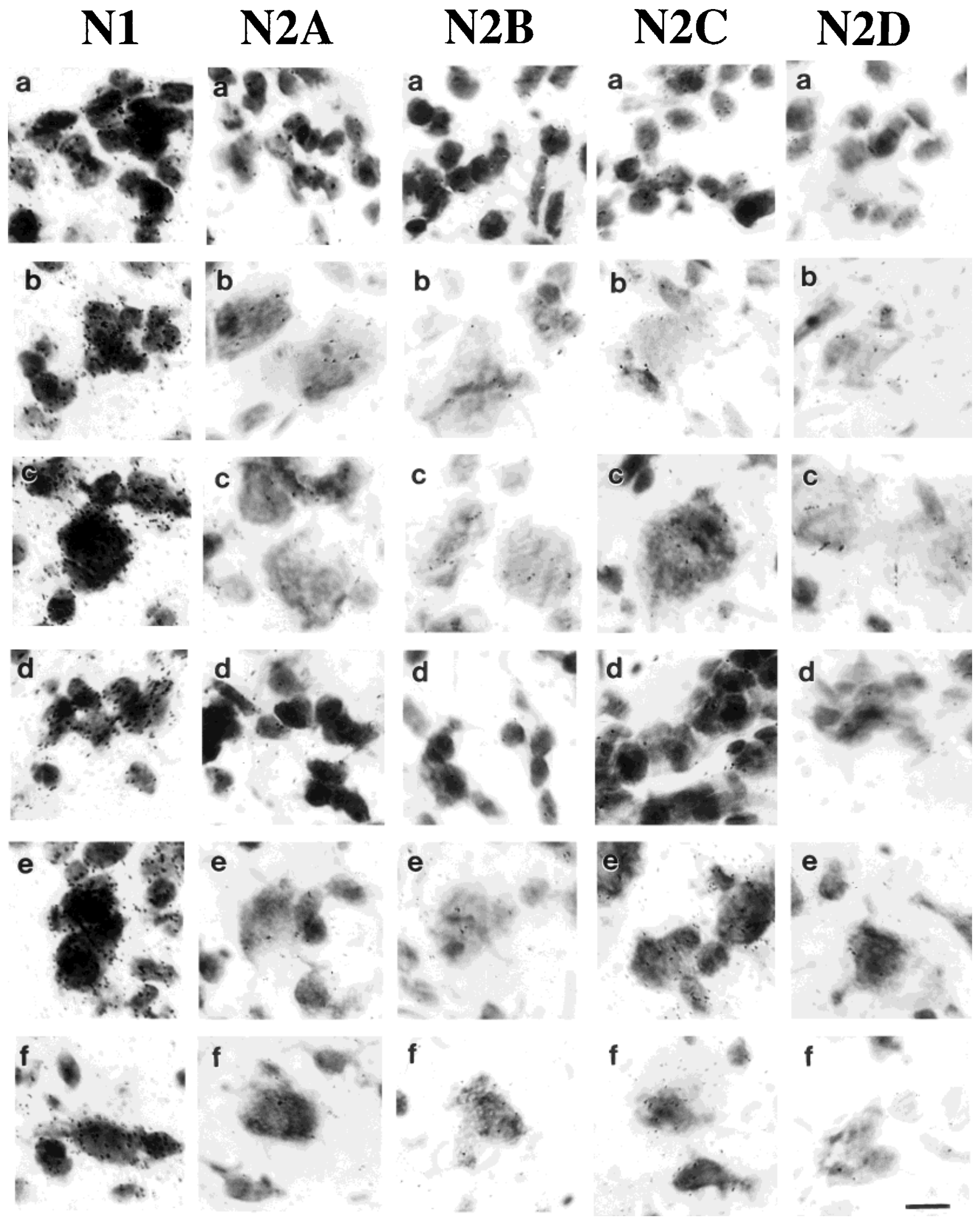

Fig. 1. Typical expression of NMDAR subunit mRNAs in the rat CN using the radioactive in situ hybridization method. a: Small cells in AVCN. b: Spherical bushy cells in AVCN. c: Octopus cells in PVCN. d: Granule cells located between ventral cochlear nucleus and DCN. e: Fusiform cells in middle layer of DCN. f: Corn cells in deep layer of DCN. Scale bar $=10 \mu \mathrm{m}$. 
TABLE 1. Mean silver grain density labeling of NMDAR2A-D mRNA for each of six cochlear nucleus cells types $\left(\times 10^{-2} \text { counts/ } \mu \mathrm{m}^{2}\right)^{1}$

\begin{tabular}{lccccrc}
\hline & SCC & SBC & OC & GC & FC & CC \\
\hline NMDAR2A & $7.0 \pm 0.9$ & $5.2 \pm 0.3$ & $3.7 \pm 0.2$ & $4.4 \pm 0.6$ & $4.3 \pm 0.5$ & $3.8 \pm 0.5$ \\
NMDAR2B & $7.3 \pm 0.9$ & $3.9 \pm 0.3$ & $4.6 \pm 0.3$ & $3.9 \pm 0.2$ & $3.8 \pm 0.3$ & $4.9 \pm 4.9$ \\
NMDAR2C & $9.6 \pm 0.8$ & $4.2 \pm 0.2$ & $4.7 \pm 0.1$ & $4.9 \pm 0.7$ & $9.1 \pm 1.1$ & $6.8 \pm 0.9$ \\
NMDAR2D & $4.5 \pm 0.4$ & $4.9 \pm 0.2$ & $3.5 \pm 0.4$ & $3.7 \pm 0.4$ & $3.9 \pm 0.5$ & $4.0 \pm 0.7$ \\
\hline
\end{tabular}

${ }^{1}$ The average silver grain density labeling of NMDAR2A-D mRNA for each of six cochlear nucleus cell types. SCC, small cells of cap overlying AVCN; SBC, spherical bushy cells in rostral AVCN; OC, octopus cells in PVCN; GC, granule cells between ventral and dorsal cochlear nucleus; FC, fusiform cells in middle layer of dorsal cochlear nucleus; CC, corn cells in deep layer of dorsal cochlear nucleus.

TABLE 2. Expression of NMDAR2 subunits in the rat CN

\begin{tabular}{lcccc}
\hline Cell type & $2 \mathrm{~A}$ & $2 \mathrm{~B}$ & $2 \mathrm{C}$ & $2 \mathrm{D}$ \\
\hline SBC & ++ & + & + & + \\
SCC & +++ & +++ & ++++ & + \\
FC & + & + & +++ & + \\
CC & + & + & ++ & + \\
GC & + & + & + & + \\
OC & + & + & + & +
\end{tabular}

${ }^{1}$ Comparison of relative labeling for NMDAR2A-D subunits in six cochlear nucleus cells types. SCC, small cells of cap overlyingAVCN; SBC, spherical bushy cells in rostral AVCN; OC, octopus cells in PVCN; GC, granule cells between ventral and dorsal cochlear nucleus; FC, fusiform cells in middle layer of dorsa cochlear nucleus; CC, corn cells in deep layer of dorsal cochlear nucleus. Labeling between $3-5 \times 10^{-2}$ counts $/ \mathrm{um}^{2}$ was considered low $(+)$, between $6-8 \times 10^{-2}$ counts $/ \mu \mathrm{m}^{2}$ considered medium $(++)$, and over 9 counts/ $\mu \mathrm{m}^{2}$ considered heavy $(+++)$.

sensitivity to D-2-amino-5-phosphonovalerate (APV) (Mishina et al., 1993). High expression of NMDAR2D confers sensitivity to glycine and L-glutamate (for review seeM ishina et al., 1993). The differential expressions of subunits in CN may, therefore, predict pharmacological properties.

In the present study, at least three distinct patterns of NMDAR2 expression were observed in the CN cells assessed. Small cells of the small cell caps/shell, fusiform cells, and corn cells of deep DCN all have relatively high NMDAR2C compared to other NMDAR2 subunits, with the level lower in corn cells (one could possibly consider these still another distinct group). Relatively high levels of NMDAR2C would confer increased sensitivity to 7CK (Monaghan et al., 1989). Spherical bushy cells had higher NMDAR2A than the other subunits, which correlates with antagonist preferring pharmacology in other regions (Buller et al., 1994; Mishina et al., 1993). Granule cells and octopus cells had relatively equival ent low levels of the four NMDR2 subunits. The NMDAR2D subunit was expressed at relatively low levels in all CN neurons, which would suggest that glycine modulation is not a prominent feature of any CN neuron. Nitric oxide synthase (NOS), an enzyme for nitric oxide formation, has recently been shown to be associated with neurons showing high expression of the NMDAR2B subunit (Brenman et al., 1996; Kornau et al., 1995). None of the CN neurons that we assessed had NMDAR2B labeling higher than the other NMDAR2 subunits, as we have observed to be the case in MNTB principal cells (Altschuler et al., 1997). NMDAR2B was, however, at high $(+++)$ levels in small cells of the small cell cap although relatively lower than NMDAR2C $(++++)$. It would be interesting to see if NOS is preferentially associated with these or any specific $\mathrm{CN}$ cells.

Our results and those of Watanabe et al. (1993) are comparable for both small cells of the small cell cap and spherical bushy cells. Both studies show higher 2C and lower 2A, 2B, and 2D in small cells, and higher 2A and lower 2B-D in spherical bushy cells. Watanabe et al. (1993) found lower levels in globular bushy than spherical bushy cells. We did not quantitate levels in gl obular bushy cells but found qualitatively similar labeling in globular and spherical bushy cells. In our studies, fusiform cells of the DCN had high NMDAR2C and lower 2A and 2B while Watanabe et al. (1993) found high $2 \mathrm{~B}$ and $2 \mathrm{C}$ and lower $2 \mathrm{~A}$. These differences could result from differences in the method of assessment (silver grain counting on emulsion dipped slides in the present study vs. intensity measures from film overlay by Watanabe et al., 1993) from other methodological differences or from differences in the age of rats assessed.

Bilak et al. (1996) recently showed diversity in the expression of NMDARI between CN neurons in the mouse using both immunocytochemistry and in situ hybridization. They reported the highest regional staining levels for NMDAR1 in the small cell shell and molecular layer of the DCN. We find that these small cells also have the highest levels of 2A-C expression (we did not assess any cell types of the DCN molecular layer). Bilak et al. (1996) did not observe NMDAR1 expression in DCN granule cells. They also reported high levels of NMDAR 1 immunostaining in the somata of stellate/multipolar and octopus cells of the VCN, in cartwheel, fusiform, corn, and several types of small cells of the DCN and in granule cells of the shell areas. Moderate immunostaining was observed in spherical and gl obular bushy cells of the VCN. F or these neurons, there is no obvious correlation with the patterns we observe with any of the NMDAR2 subunits. It is also important to consider the recent results of Rubio and Wenthold (1997), which show different receptor subunits can be targeted to different synapses within a single neuron. Thus, for $\mathrm{CN}$ neurons that receive more than one source of excitatory amino acid input, high expression of a subunit could either reflect a great contribution to the composition of the receptor apposing a single input type or the fact that it has a role in the composition of receptors apposing multi ple input types.

The NMDAR is, of course, just one component of excitatory amino acid transmission in $\mathrm{CN}$ neurons. The AMPA receptor plays a major role in fast excitatory transmission and the properties of such transmission can, therefore, also be greatly influenced by AMPA subunit composition. When NMDAR results from our study are compared with AMPAR results of Hunter et al. (1993), no obvious correlation is seen between diversity in NMDAR2A-D subunit and diversity in GLUR1-4 subunit expressions.

Differences in NMDAR1 isoforms al so influence properties of EAA synapses, such as agonist and antagonist 
potency, phosphorylation, and potentiation by protein kinase C (PKC) activators (Anantharam et al., 1992; Durand et al., 1993; Hollmann et al., 1993; Tingley et al., 1993). Preliminary reports by Hunter et al. (1995) predict diversity in expression of these isoforms in the $\mathrm{CN}$. It will be interesting to see how NMDAR1 isoform distribution correlates with diversity in expression of NMDAR2 subunits.

The results of the present study, showing different patterns in expression of NMDAR2 subunits in the rat $\mathrm{CN}$, add to other studies of the NMDAR1 and AMPA receptors to show a diversity in expression between $\mathrm{CN}$ neuronal types and suggest that EAA synapses in the $\mathrm{CN}$ are "fine-tuned" to provide the properties best suited for their functional requirements. Moreover, recent preliminary studies on changes with deafness suggest that subunit expression and functional properties of auditory brain stem neurons may be able to react and adapt to changes in inputs (Altschuler et al., 1997; Hunter et al., 1995; Sato and Altschuler, 1996).

\section{ACKNOWLEDGMENTS}

We thank Professor Tetsuo Sugimoto, Department of Anatomy, Kansai Medical University, Osaka, J apan, for helpful suggestions about in situ hybridization methods. This work was supported by NIDCD grant DC00383.

\section{REFERENCES}

Adams, J.C. (1993) Non-primary inputs to the cochlear nucleus visualized using immunocytochemistry. In: The Mammalian Cochlear Nuclei: Organization and Function. M.A. Merchan, J .M. J uiz, D.A. Godfrey, and E. Mugnaini, eds. Plenum Press, New York, pp. 133-142.

Altschuler, R.A., H offman, D.W., and Wenthold, R.J . (1986) Neurotransmitters of the cochlea and cochlear nucleus. Am. J . Otolaryngol., 7:100-106.

Altschuler, R.A., Sato, K., Dupont, J ., Bonneau, J .B., and Nakagawa, $\mathrm{H}$. (1997) NMDA and glycine receptors in the auditory brain stem: Diversity and changes with deafness. In: Acoustic Signal Processing in the Central Auditory System. J. Sykka, ed. Plenum Press, New York.

Anantharam, V., Panchal, R.G., Wilson, A., Koltchine, V.V., Treistman, S.N., and Bayley, H. (1992) Combinationial RNA splicing alters the surface charge on the NMDA receptor. FEBS Lett., 305:27-30.

Bilak, M.M., Bilak, S.R., and Morest, D.K. (1996) Differential expression of N-methyl-D-aspartate receptor in the cochlear nucleus of the mouse. Neuroscience, 75:1075-1098.

Brenman, J.E., Chao, D.S., Gee, S.H., McGee, A.W., Craven, S.E., Santillano, D.R., Wu, Z., Huang, F., Xia, H., Peters, M.F., Froehner, S.C., and Bredt, D.S. (1996) Interaction of nitric oxide synthase with the postsynaptic density protein PSD-95 and alphal-syntrophin mediated by PDZ domains. Cell, 84:757-767.

Buller, A.L., Larson, H.C., Schneider, B.E., Beaton, J .A., Morrisett, R.A., and Monaghan, D.T. (1994) The molecular basis of NMDA receptor subtypes: Native receptor diversity is predicted by subunit composition. J. Neurosci., 9:5471-5484.

Cant, N.B., and Morest, D.K. (1984) The functional basis for stimulus coding in the cochlear nucleus. In: Hearing Sciences: Recent Advances. C. Berlin, ed. College Hill Press, San Diego, pp. 371-422.

Caspary, D.M. (1986) Cochlear nuclei: F unctional neuropharmacology of the principal cell types. In: Neurobiology of Hearing: The Cochlea. R.A. Altschuler, R.P. Bobbin, and D.W. Hoffman, eds. Raven Press, New York, pp. 303-332.

Caspary, D.M., and Finlayson, P.G. (1991) Superior olivary complex: F unctional neuropharmacology of the major cell types. In: Neurobiology of Hearing: The Central Auditory System. R.A. Altschuler, R.P. Bobbin, B.C. Clopton, and D.W. Hoffman, eds. Raven Press, New York, pp. 141-163.

Caspary, D.M., Rybak, L.P., and Faingold, C.L. (1985) The effects of inhibitory and excitatory amino acid neurotransmitters on the response properties of brainstem auditory neurons. In: Auditory Biochemistry. D.G. Drescher, ed. Thomas Publishing, Springfield, IL, pp. 198-226.
Cik, M., Chazot, P.L., and Stephenson, F.A. (1993) Optical expression of cloned NMDAR 1/NMDAR 2A heteromeric glutamate receptors: A biochemical characterization. Biochem. J ., 296:877-883.

Collingridge, G.L., Herron, C.E., and Lester, R.A.J . (1988) Frequencydependent $\mathrm{N}$-methyl-D-aspartate receptor mediated synaptic transmission in the rat hippocampus. J . Physiol. (L ond)., 399:301-312.

Cotman, C.W., and I versen, L.L. (1987) Excitatory amino acids in the brain focus on NMDA-receptor. Trends Neurosci., 10:263-265.

Durand, G.M., Bennet, M.V.L., and Zukin, R.S. (1993) Splice variants of the N-methyl-D-aspartate receptor NR 1 identify domains involved in regulation by polyamines and protein kinase C. Proc. Natl. Acad. Sci. U.S.A., 90:6731-6735.

Esclapez, M., Tillakaratne, N.J.K., Tobin, A.J ., and Houser, C.R. (1993) Comparative localization of mRNAs encoding two forms of glutamic acid decarboxylase with nonradioactive in situ hybridization methods. J. Comp. Neurol., 15:339-362.

Eybalin, M. (1993) Neurotransmitters and neuromodulators of the mammalian cochlea. Physiol. Rev., 73:309-373.

Godfrey, D.A., Parli, J .A., Dunn, J .D., and Ross, C.D. (1988) Neurotransmitter microchemistry of the cochlear nucleus and the superior olivary complex. In: Auditory Pathways. J . Syka, and R.L. Masterton, eds. Plenum Press, New York, pp. 107-121.

Helfert, R.H., Snead, C.R., and Altschuler, R.A. (1991) The ascending auditory pathways. In: Neurobiology of Hearing: The Central Auditory System. R.A. Altschuler, R.P. Bobbin, B.M. Clopton, and D.W. Hoffman, eds. Raven Press, New York, pp. 1-26.

Hollmann, M., Boulter, J ., Maron, C., Beasley, L., Sullivan, J ., Pecht, G., and Heinemann, S. (1993) Zinc potentiates agonist-induced currents at certain splice variants of the NMDA receptor. Neuron, 10:943-954.

Hunter, C., Petralia, R.S., Vu, T., and Wenthold, R.J . (1993) Expression of AMPA-selective glutamate receptor subunits in morphologically defined neurons of the mammalian cochlear nucleus. J . Neurosci., 13:1932-1946.

Hunter, C., Mathura, J., and Wenthold, R.J . (1995) Expression of NMDA selective glutamate receptor NR1 isoforms in the rat cochlear nucleus. Abstr. Assoc. Res. Otolaryngol., 18:30.

Hutson, K.A., and Morest, D.K. (1996) Fine structure of the cell clusters in the cochlear nerve root: Stellate, granule and mitt cells offer insights into the synaptic organization of local circuit neurons. J. Comp. Neurol. 371:397-414.

J uiz, J .M., Rubio, M.E., Helfert, R.H., and Altschuler, R.A. (1993) Localizing putative excitatory endings in the cochlear nucleus by quantitative immunocytochemistry. In: The Mammalian Cochlear Nuclei: Organization and Function. M.A. Merchan, J .M. J uiz, D.A. Godfrey, and E. Mugnaini, eds. Plenum Press, New York, pp. 167-178.

Kornau, H.-C., Schenker, L.T., Kennedy, M.B., and Seeburg, P.H (1995) Domain interaction between NMDA receptor subunits and the postsynaptic density protein PSD-95. Science, 269:1737-1740.

Kusiak, J .M., and Norton, D.D. (1993) A splice variant of N-methyl-Daspartate (NMDAR1) receptor. Mol. Brain Res., 20:67-70.

Kutsuwada, T., Kashiwabuchi, N., Mori, H., Sakimura, K., Kushiya, E., Araki, K., Meguro, H., Masaki, H., Kumanishi, T., Arakawa, M., and Mishina, M. (1992) Molecular diversity of the NMDA receptor channel. Nature, 358:36-41.

Laurie, D.J ., and Seeburg, P.H. (1994) Regional and developmental heterogeneity in splicing of the rat brain NMDAR1 mRNA. J. Neurosci., 14:3180-3194.

Manis, P.B., Scott, J.C., and Spirou, G.A. (1993) Physiology of the dorsal cochlear nucleus molecular layer. In: The Mammalian Cochlear Nuclei: Organization and Function. M.A. Merchan, J .M.J uiz, D.A. Godfrey, and E. Mugnaini, eds. Plenum Press, New York, pp. 361-372.

Mishina, M., Mori, H., Araki, K., Kushiya, E., Meguro, H., Kutsuwada, T., Kashiwabuchi, N., Ikeda, K., Nagasawa, M., Yamazaki, M., Masaki, H., Yamakura, T., Morita, T., and Sakimura, K. (1993) Molecular and functional diversity of the NMDA receptor channel. In: Molecular Basis of I on Channels and Receptors Involved in Nerve Excitation, Synaptic Transmission and Muscle Contraction. H. Higashida, T. Yoshioka, and K. Mikoshiba, eds. The New York Academy of Science, New York, pp. 136-152.

Monaghan, D.T., and Cotman, C.W. (1985) Distribution of N-methyl-Daspartate-sensitive $\mathrm{L}-\left[{ }^{3} \mathrm{H}\right]$ glutamate-binding sites in rat brain. J . Neurosci., 5:2909-2919.

Monaghan, D.T., Bridges, R.J ., and Cotman, C.W. (1989) The excitatory amino acid receptor: Their classes, pharmacology and distinct properties in the function of the central nervous system. Rev. Pharmacol. Toxicol., 29:365-402.

Monyer, H., Seeburg, P.H., and Wisden, W. (1991) Glutamate-operated 
channels: Devel opmentally early and mature forms arise by alternative splicing. Neuron, 6:799-810.

Monyer, H., Sprengel, R., Schoepter, R., Herb, A., Higuch, M., Lomel, H., Burnashev, N., Sakmann, B., and Seeburg, P.H. (1992) Heteromeric NMDA-receptor; molecular and functional distinction of subtypes. Science, 256:1217-1221.

Moore, J.K. (1986) Cochlear nuclei: Relationship to the auditory nerve In: Neurobiology of Hearing: The Cochlea. R.A. Altschuler, D.W. Hoffman, and R.P. Bobbin, eds. Raven Press, New York, pp. 283-301.

Morest, D.K. (1993) A cellular basis for signal processing in the mammalian cochlear nucleus. In: The Mammalian Cochlear Nuclei Organization and Function. M.A. Merchan, J .M. J uiz, D.A. Godfrey, and E. Mugnaini, eds. Plenum Press, New York, pp. 1-18.

Moriyoshi, K., Masu, M., Ishii, T., Shigemoto, R., Mizuno, N., and Nakanishi, S. (1991) Molecular cloning and characterization of the rat NMDA receptor. Nature, 354:31-37.

Nakanishi, S. (1992) Molecular diversity of glutamate receptors and implications for brain function. Science, 258:597-603.

Nakanishi, N., Shneider, N.A., and Axel, R. (1990) A family of glutamate receptor genes: Evidence for the formation of heteromultimeric receptors with distinct channel properties. Neuron, 5:569581.

Nakanishi, N., Axel, R., and Shneider, N.A. (1992) Alternative splicing generates functionally distinct $\mathrm{N}$-methyl-D-aspartate receptors. Proc. Natl. Acad. Sci. U.S.A., 89:8552-8556.

Petralia, R.S., Yokotani, N., and Wenthold, R.J . (1994a) Light and electron microscope distribution of the NMDA receptor subunit NMDAR 1 in the rat nervous system using a selective anti-peptide antibody. J . Neurosci., 14:667-696.

Petralia, R.S., Wang, Y.-X., and Wenthold, R.J . (1994b) Comparative distribution of glutamate receptor subunits in the cochlear nuclei of the rat using characterized antipeptide antibodies. Abst. Assoc. Res. Otolaryngol., 17:14.

Petralia, R.S., Wang, Y.X., Zhao, H.M., and Wenthold, R.J . (1996) I onotropic and metabotrophic glutamate receptors shown unique postsynaptic, presynaptic and glial localizations in the dorsal cochlear nucleus. J. Comp. Neurol., 372:356-383.

Raditsch, M., Rupperburg, J .P., Kuner, T., Günther, W., Schoepfer, R. Seeburg, P.H., J ahn, W., and Witzemann, V. (1993) Subunit-specific block of cloned NMDA receptors by argiotoxin ${ }_{636}$. FEBS Lett., 324:63-66.

Rubio, M.E., and Wenthold, R.J. (1997) Glutamate receptors are selectively targeted to postsynaptic sites in neurons. Neuron, 18: 939-50.
Sato, K., and Altschuler, R.A. (1996) Deafness induced changes in NMDA receptor mRNA expression in the rat cochlear nucleus and superior olivary complex. Abst. Assoc. Res. Otolaryngol., 19:116.

Sato, K., Kuriyama, H., and Altschuler, R.A. (1995a) Expression of glycine receptor subunits in the cochlear nucleus and superior olivary complex using non-radioactive in situ hybridization. Hear. Res., 91:7-18.

Sato, K., Kuriyama, H., Bonneau, J.M., and Altschuler, R.A. (1995b) Expression of NMDA-receptor in the rat cochlear nucleus and superior olivary complex. Abst. Assoc. Res. Otolaryngol., 18:31.

Schwartz, I.R., and Eager, P.R. (1995) Ultrastructural localization of glutamate receptor subunit immunor eactivity in the cochlear nucleus and superior olivary complex. Abst. Assoc. Res. Otolaryngol., 18:39.

Shigemoto, R., Ohishi, H., Nakanishi, S., and Mizuno, N. (1992) Expression of the mRNA for the rat NMDA receptor (NMDA R1) in the sensory and autonomic ganglion neurons. Neurosci. Lett. $144: 229-232$

Standaert, D.G., Testa, C.M., Penny, J .B. J r., and Young, A.B. (1993) Alternatively spliced isoforms of the NMDAR1 glutamate receptor subunit: Differential expression in the basal ganglia of the rat. Neurosci. Lett, 152:161-164.

Tingley, W.G., Roche, K.W., Thompson, A.K., and Huganir, R.L. (1993) Regulation of NMDA receptor phosphorylation by alternative splicing of the C-terminal domain. Nature, 364:70-73.

Tölle, T.R., Berthele, A., Zieglgänsberger, W., Seeburg, P.H., and Wisden, W. (1993) The differential expression of 16 NMDA and non-NMDA receptor subunits in the rat spinal cord and in periaqueductal gray. J . Neurosci., 13:5009-5028.

Watanabe, M., Inoue, Y., Sakimura, K., and Mishina, M. (1993) Distinct distributions of five $\mathrm{N}$-methyl-D-aspartate receptor channel subunit mRNAs in the forebrain. J . Comp. Neurol ., 338:377-390.

Watkins, J .C., Krogasgaard-Larsen, P., and Horore, T. (1990) Structureactivity relationships in the development of excitatory amino acid receptor agonists and competitive antagonist. Trends Pharmacol. Sci., 11:25-30.

Wenthold, R.J . (1991) Neurotransmitters of brainstem auditory nuclei. In: Neurobiology of Hearing, The Central Auditory System. R.A. Altschuler, R.P. Bobbin, B.M. Clopton, and D.W. Hoffman, eds. Raven Press, New York, pp. 121-140.

Wenthold, R.J ., Hunter, C., and Petralia, R.S. (1993) Excitatory amino acid receptors in the rat cochlear nucleus. In: The Mammalian Cochlear Nuclei: Organization and Function. M.A. Merchan, J.M. J uiz, D.A. Godfrey, and E. Mugnaini, eds. Plenum Press, New York, pp. 179-94. 